\title{
Lysozyme: a brief review
}

\author{
M. Afzal Mir \\ M.B., D.C.H., M.R.C.P. \\ University Department of Cardiology, Manchester Royal Infirmary, Manchester M13 9WL
}

\begin{abstract}
Summary
Serum lysozyme (muramidase) estimation is a simple, convenient and useful laboratory investigation. A review of the literature shows that lysozyme has been implicated as an aetiological factor in various disorders, and credited with being a prognostic indicator in acute myeloid leukaemia, but these promises have not been fulfilled. This low molecular weight protein is found in the urine of some patients with renal tubular disorders, but some workers have emphasized its importance as a causal agent in hypokalaemia of acute myeloid leukaemia. Research should be concentrated on muramidase as an expression of cell functions rather than as an aetiological factor. Hypokalaemia in acute myeloid leukaemia may be caused by an unidentified substance of molecular weight similar to that of lysozyme.
\end{abstract}

FLEMING discovered a 'remarkable bacteriolytic element in tissues and secretions' in 1922 and called it lysozyme (muramidase). He is reputed to have said, 'We shall hear more about lysozyme' (Osserman, 1975). A truly remarkable foresight but even he could not have imagined that in the next 54 years lysozyme would be associated with any abnormality that happens to be associated with an elevated level of this low molecular weight protein.

An increased lysozyme activity in the gastric juice of patients with peptic ulcer prompted Meyer et al. (1948b) to suggest a causal relationship between the two. Although Fleming had already demonstrated lysozyme in the intestines, its increased activity in the colonic secretions of patients with ulcerative colitis and regional enteritis, induced some workers (Meyer et al., 1948a; Prudden, Lane and Levison, 1949a) to postulate that lysozyme was an aetiological factor in these disorders. Further work by Prudden, Lane and Meyer (1949b) and by others (Hiatt et al., 1952) showed that a large population of granulocytes was responsible for the increased concentration of lysozyme in colonic mucus. It is now known that granulocytes and macrophages elaborate lysozyme, and its increased concentration in colonic exudate is secondary to an increased invasion of colon by these cells, as would be expected in inflammatory conditions such as ulcerative colitis and Crohn's disease.
Osserman and Lawlor (1966) in their excellent paper on lysozyme reported that some of their patients with acute myeloid leukaemia had hypokalaemia and excreted large quantities of lysozyme in the urine. These authors thought the two abnormalities were probably related. Muggia et al. (1969) found hyperkaluria in some leukaemic patients with hypokalaemia and lysozymuria, and they suggested that lysozyme was probably responsible for renal potassium wasting and hypokalaemia. Pickering and Catovsky (1973) found a significant negative correlation between serum $\mathrm{K}$ and serum lysozyme but Pruzanski and Platts (1973) found no correlation between hypokalaemia and urinary or serum lysozyme. Mir and his co-workers (1975a) carried out potassium balance studies in thirty-two patients with acute myeloid leukaemia; twelve had hyperkaluria but only seven of these had lysozymuria.

While the aetiological significance of lysozyme in leukaemic patients with hypokalaemia remained unsettled, some workers have examined their data to see if lysozyme has any prognostic value. Wiernik and Serpick (1969) found that patients with acute myeloid leukaemia, who had elevated initial serum muramidase levels, fared worse than those with normal or low levels. Castro, Perillie and Finch (1970) came to the opposite conclusion: they reported that patients with high serum lysozyme levels live longer than those with low levels. Currie (1976) attached prophetic significance to serum lysozyme in acute myeloid leukaemia. He was able to divide his eighty-eight patients into three groups; all nineteen patients with serum lysozyme less than $15 \mu \mathrm{g} / \mathrm{ml}$ (normal 5.1-9.7 $\mu \mathrm{g} / \mathrm{ml}$ ) failed to achieve remission, all ten patients with levels above $85 \mu \mathrm{g} / \mathrm{ml}$ responded to antileukaemic treatment, and the patients with serum lysozyme in between these two extremes did moderately well. Other workers have failed to confirm these findings (Mir, 1976; McCarthy et al., 1976).

Lysozyme has been employed as a diagnostic tool by some workers: Falchuk, Perrotto and Isselbacher (1975a) found raised serum levels in Crohn's disease but not in ulcerative colitis. Pancytopenia can be a difficult diagnostic problem and serum lysozyme level has been used to differentiate between aleukaemic leukaemia (high) and aplastic anaemia (low) 
(Firkin, 1972). Raised lysozyme levels have also been reported in pancytopenia of megaloblastic anaemia (Perillie, Kaplan and Finch, 1967). An elevated serum lysozyme level can often be helpful in distinguishing acute myeloid leukaemia from acute lymphatic leukaemia, which is associated with low lysozyme activity (Jolles, Steinberg and Mathe, 1965; Perillie et al., 1968).

The diagnostic value of lysozyme is not invariable since an elevated serum level is not always found in conditions known to have high lysozyme activity. The inadequacy of morphological and histochemical techniques is not always helped by a simple lysozyme estimation in a difficult diagnostic problem of blastaemia: low serum lysozyme level may be invariable in acute lymphatic leukaemia but low levels are also common in acute myeloid leukaemia (Osserman and Lawlor, 1966; Perillie et al., 1968; Mir et al., 1975a; Currie, 1976; Mir, 1976). Uncertainty also accompanies the diagnostic use of lysozyme in inflammatory bowel disorders: Falchuk et al. (1975a) found raised serum levels in Crohn's disease but not in ulcerative colitis; Pounder et al. (1975) found raised levels in both conditions while Peters, Geboes and Vantrappen (1975), and Johansson and Ursing (1976) did not find elevated levels in either disease. These discrepancies could be caused by differences in methods, in patient population as well as in the stages of disease during which the patients were studied by various workers.

The differences in methodology apart, it seems quite acceptable that serum lysozyme level should be elevated in the active phase of Crohn's disease as shown by Falchuck, Perrotto and Isselbacher (1975b), as there is an increased infiltration of the bowel by lysozyme producing cells (i.e. macrophages, granulocytes, etc.). An elevated serum level in pancytopenia favours leukaemia rather than aplastic anaemia, and when the morphological features of blast cells are not distinctly helpful, acute myeloid leukaemia is probable in the presence of an elevated serum muramidase level. At present it is difficult to accept that lysozyme is of any prognostic importance because its serum levels may reflect the extent of tumour mass in the body, but we do not know the sensitivity of such a mass to cytotoxic therapy. Future studies may reveal various subtypes of muramidase based on more sophisticated physical and biochemical characteristics, and these subtypes may reveal more about the cell functions and about their sensitivity to antitumour drugs.

The aetiological role of lysozyme in hyperkalaemia and the associated renal tubular dysfunction have been questioned. The involvement of lysozyme was based on the fact that lysozymaemia and hyperkaluria occurred together in some patients with acute myeloid leukaemia (Osserman and Lawlor, 1966; Muggia et al., 1969; Pickering and Catovsky, 1973). Lysozymuria has been reported in various renal tubular disorders as a manifestation of the disease (Butler and Flyn, 1961; Kazantzis et al., 1963; Prockop and Davidson, 1964; Harrison et al., 1968). Hypokalaemia may occur in patients with normal lysozyme; and high lysozyme levels are not always associated with low serum $\mathrm{K}$ levels (Pruzanski and Platts, 1973; Mir et al., 1975a). Klockars et al. (1974) observed proximal renal tubular lesions in chloroleukaemic rats with elevated lysozyme levels, but these workers were unable to reproduce such lesions in normal rats after the intra-aortic administration of lysozyme. Other workers (Rosenthal, Maglio and Moloney, 1972; Greenberger, Rosenthal and Moloney, 1973) have demonstrated in chloroleukaemic and normal rats that only prolonged elevation in serum lysozyme causes lysozymuria and hyperkaluria. Mason, Howes and Taylor (1975) found no tubular maximum (Tm) for resorption of lysozyme in the perfused rat kidney, and lysozymuria occurred even at low perfusate levels of lysozyme. These workers demonstrated an increased $\mathrm{K}$ and $\mathrm{Na}$ excretion as the lysozyme concentration was increased in the perfusate. Mack (1975) showed that Tm for lysozyme was about $1000 \mu \mathrm{g} / \mathrm{min}$ but lysozymuria occurred at normal filtered load of $50 \mu \mathrm{g} / \mathrm{min}$.

How far can these studies in rats be extrapolated to apply to humans? Mir et al. (1975b) correlated total glomerular filtered load with hypokalaemia in seven patients with acute myeloid leukaemia. Three of their patients developed hypokalaemia at lower than normal filtered lysozyme loads. Proximal renal tubular dysfunction has been reported in acute myeloid leukaemia in association with normal serum lysozyme levels (Mir and Delamore, 1974). Leukaemic plasma has been found to inhibit $\mathrm{Na}$ efflux from erythrocytes (Mir and Bobinski, 1975). Lysozymuria, hypokalaemia and hyperkaluria may therefore all be manifestations of widespread renal tubular dysfunction caused by some other unidentified substance of similar molecular weight, released from blast cells, which is nephrotoxic and is excreted by leukaemic patients in their urine.

\section{References}

Butler, E.A. \& Flyn, F.V. (1961) The occurrence of postgamma protein in urine: A new protein abnormality. Journal of Clinical Pathology, 14, 172.

Castro, D., Perillie, P.E. \& Finch, S.C. (1970) Lysozyme in relation to the clinical characteristics of adult acute leukaemia. Abstracts of Thirteenth International Congress of Haematology, Munich, p. 231.

CurRIE, G. (1976) Prognostic significance of serum lysozyme in adult myelogenous leukaemia. Lancet, i, 835.

Falchuk, K.R., Perrotto, J.L. \& Isselbacher, J. (1975a) Serum lysozyme in Crohn's disease and ulcerative colitis. New England Journal of Medicine, 292, 395. 
Falchuk, K.R., Perrotto, J.R. \& Isselbacher, J. (1975b) Serum lysozyme in Crohn's disease. A useful index of disease activity. Gastroenterology, 69, 893.

FIRKIN, F.C. (1972) Serum muramidase in haematological disorders: diagnostic value in neoplastic disorders. Australian and New Zealand Journal of Medicine, 1, 28.

Fleming, A. (1922) On remarkable bacteriolytic element found in tissues and secretions. Proceedings of the Royal Society, London, Series B. 93, 306.

Greenberger, J.S., Rosenthal, D.S. \& Moloney, W.C. (1973) Studies on hypermuramidasemia in the normal and chloroleukemic rat: the role of the kidney. Journal of Laboratory and Clinical Medicine, 81, 116.

Harrison, J.F., LUNt, G.S., Scott, P. \& Blainey, J.D. (1968) Urinary lysozyme, ribonuclease and low molecular weight protein in renal disease. Lancet, i, 371.

Hiatt, R.B., Engle, C., Flood, C. \& Karush, A. (1952) The role of granulocyte as a source of lysosyme in ulcerative colitis. Journal of Clinical Investigation, 31, 721.

Johansson, B.G. \& URsing, B. (1976) Lysozyme in Crohn's disease: influence of methods (letter). New England Journal of Medicine, 294, 337.

Jolles, P., Steinberg, M. \& Mathe, G. (1965) The relationship between serum lysozyme levels and the blood leucocytes. Israel Journal of Medical Science, 1, 445.

Kazantzis, G., Flyn, F.V., Spowage, J.S. \& Trott, D.G. (1963) Renal tubular malfunction and pulmonary emphysema in cadmium pigment workers. Quarterly Journal of Medicine, 32, 165.

Klockars, M., Azar, H.A., Hermida, R., Isobe, T., Hsu, C.C.S., ANSARI, H. \& OsSErman, E.F. (1974) The relationship of lysozyme to the nephropathy in chloroleukemic rats and the effects of lysozyme loading on normal rat kidneys. Cancer Research, 34, 47.

McCarthy, D., Fitzgerald, G., Hegarty, J., Goodwin, F. \& O'Connell, L.G. (1976) Prognostic significance of serum lysozyme in A.M.L. (letter). Lancet, i, 1075.

MACK, T. (1975) Renal handling of low molecular weight proteins. American Journal of Medicine, 58, 57.

MAson, D.Y., Howes, D.T. \& TAYLOR, C.R. (1975) Effect of human lysozyme (muramidase) on potassium handling by the perfused rat kidney. Journal of Clinical Pathology, 28, 722.

Meyer, K., Gellhorn, A., Prudden, J.F., Lehman, W.L. \& SteINBerg, A. (1948a) Lysozyme activity in ulcerative alimentary disease. II. Lysozyme activity in chronic ulcerative colitis. American Journal of Medicine, 5, 496.

Meyer, K., Prudden, J.F., Lehman, W.L. \& Steinberg, A. (1948b) Lysozyme activity in ulcerative alimentary disease. 1. Lysozyme in peptic ulcer. American Journal of Medicine, 5, 482.

MIR, M.A. (1976) Prognostic significance of serum lysozyme in A.M.L. (letter). Lancet, i, 1075.

Mir, M.A. \& BobINSKI, H. (1975) Altered membrane sodium transport and the presence of a plasma ouabain-like inhibitory factor in acute myeloid leukaemia. Clinical Science and Molecular Medicine, 48, 213.

Mir, M.A., Brabin, B., Tang, O.T., Leyland, M.J. \& Delamore, I.W. (1975a) Hypokalaemia in acute myeloid leukaemia. Annals of Internal Medicine, 82, 54.
Mir, M.A., Brabin, B., Tang, O.T., Leyland, M.J. \& Delamore, I.W. (1975b) Hypokalaemia in acute leukaemia (letter). Annals of Internal Medicine, 82, 855.

Mir, M.A. \& Delamore, I.W. (1974) Hypouricaemia and proximal renal tubular dysfunction in acute myeloid leukaemia. British Medical Journal, 3, 775.

Muggia, F.M., Heinmann, H.O., Farhangi, M. \& OsserMAN, E.F. (1969) Lysozymuria and renal tubular dysfunction in monocytic and myelomonocytic leukaemia. American Journal of Medicine, 47, 351.

Osserman, E.F. (1975) Lysozyme. New England Journal of Medicine, 292, 424.

Osserman, E.F. \& Lawlor, D.P. (1966) Serum and urinary lysozyme (muramidase) in monocyt ic and myelomonocytic leukemia. Journal of Experimental Medicine, 124, 921.

Perillie, P.E., Kaplan, S.S. \& Finch, S.C. (1967) Significance of changes in serum muramidase activity in megaloblastic anemia. New England Journal of Medicine, 277, 10.

Perillie, P.E., KaPlan, S.S., Lefkowitz, E., Rogoway, W. \& FINCH, S.C. (1968) Studies of muramidase (lysozyme) in leukemia. Journal of the American Medical Association, 203, 317.

Peters, T.L., Geboes, K. \& Vantrappen, G.R. (1975) Serum lysozyme levels in Crohn's disease (letter). New England Journal of Medicine, 292, 1349.

Pickering, T.G. \& Catovsky, D. (1973) Hypokalaemia and raised lysozyme levels in acute myeloid leukaemia. Quarterly Journal of Medicine, 42, 677.

Pounder, R.E., Avella, J.R., McCallum, H. \& Misiewicz, J.J. (1975) Serum lysozyme in inflammatory bowel disease (letter). Lancet, ii, 228.

Prockop, D.J. \& Davidson, W.D. (1964) A study of urinary and serum lysozyme in patients with renal disease. New England Journal of Medicine, 270, 269.

Prudden, J.F., Lane, N. \& Levison, J. (1949a) Lysozyme titres in regional enteritis, miscellaneous tissues, microorganisms and excreta. Proceedings of the Society for Experimental Biology and Medicine, 72, 220.

Prudden, J.F., Lane, N. \& Meyer, K. (1949b) Lysozyme content of granulation tissue. Proceedings of the Society for Experimental Biology and Medicine, 72, 38.

Pruzanski, W. \& Platts, M.E. (1973) Serum and urinary proteins, lysozyme (muramidase), and renal dysfunction in mono- and myelomonocytic leukemia. Journal of Clinical Investigation, 49, 1694.

Rosenthal, D.S., Maglio, R. \& Moloney, W.C. (1972) Muramidasuria and hyperkaluria in the chloroleukemic rat. Proceedings of the Society for Experimental Biology and Medicine, 141, 499.

Wiernik, P.H. \& SERPICK, A.A. (1969) Clinical significance of serum and urinary muramidase activity in leukemia and other hematologic malignancies. American Journal of Medicine, 46, 330. 